\title{
Description of a New Haemogregarine, Haemogregarina sundarbanensis
} n. sp. (Apicomplexa: Haemogregarinidae) from Mud Turtle of Sundarban Regions, West Bengal, India

\author{
Hindistan (Batı Bengal)'daki Kanat Kabuklu Camur Kaplumbağası’ndan Yeni Bir Haemogregarin \\ Haemogregarina sundarbanensis n. sp. (Apicomplexa: Haemogregarinidae)'in Tavsifi
}

\author{
Sabir Hossen Molla1, Probir K. Bandyopadhyay¹, Gözde Gürelli² \\ 'Department of Zoology, Parasitology Laboratory, University of Kalyani, West Bengal, India \\ ${ }^{2}$ Department of Biology, Kastamonu University Faculty of Science and Art, Kastamonu, Turkey
}

\begin{abstract}
Objective: The aim of this study was to provide a description of a new haemogregarine, Haemogregarina sundarbanensis $\mathrm{n}$. $\mathrm{sp}$., from mud turtles collected from Sundarban regions, West Bengal, India.

Methods: The turtles were collected from fish markets near Canning, South 24-Parganas District, West Bengal. Thin blood films were prepared using the blood drawn from the head and feet. The blood films were then air-dried, fixed in absolute methanol, and stained with Giemsa.

Results: The erythrocytic stages could be differentiated into small and large forms. The young gamonts measured 7.896 $\times 3.469 \mu \mathrm{m}$, microgamonts measured $8.876 \times 4.425 \mu \mathrm{m}$, and macrogamonts measured $8.919 \times 4.272 \mu \mathrm{m}$. The cytoplasm of the macrogamonts was stained deep blue with Giemsa, and many metachromatic granules are found uniformly distributed. The oval or rounded nucleus was central in position and stained deep red with Giemsa stain, whereas in microgamonts, the nucleus was not at all compact but with a few dispersed chromatin granules. Conclusion: The prevalence of infection was found to be 33.3\% (5/15). The infected erythrocytes reveal shape alteration, marginal and atrophic nucleus, and were larger than non-parasitized erythrocytes. The cytoplasm of the infected erythrocytes stained darker than that of the uninfected erythrocytes. (Turkiye Parazitol Derg 2015; 39: 131-4)
\end{abstract}

Keywords: Haemogregarine, Haemogregarina sundarbanensis n. sp., erythrocyte, India

Received: $15.10 .2014 \quad$ Accepted: 20.12.2014

\section{ÖZET}

Amaç: Bu çalışmanın amacı Hindistan'ın Batı Bengal bölgesindeki çamur kaplumbağasından yeni bir hemogregarin türünün, Haemogregarina sundarbanensis n. sp. (Apicomplexa: Haemogregarinidae)'in tavsifidir.

Yöntemler: Kaplumbağalar Batı Bengal bölgesindeki balıkhanelerden elde edilmiştir. İnce kan filmler baş ve ayaktaki kandan yapılmıştır. Kan filmleri hava yardımıyla kurutulmuş, absolü metal alkolde tespit edilmiş, Giemsa boyalarıyla boyanmıştır.

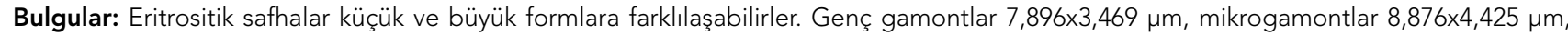
makrogamontlar 8,919x4,272 $\mu \mathrm{m}$ 'dir. Makrogamontların sitoplazması Giemsa'yla koyu mavi boyanmıştır ve çok sayıdaki metakromatik granüller düzgünce dağılmıştır. Orta pozisyondaki oval veya yuvarlak nukleus Giemsa'yla koyu kırmızı boyanmıştır, fakat mikrogamontlarda nukleus tamamiyle kompakt değildir ve bir kaç dağılmış kromatin granülleri içerir.

Sonuç: Enfeksiyon yaygınlığı \%33,3 (5/15)'tür. Enfekte eritrositler şekil değişikliği, marjinal ve atrofik nukleus gösterirler ve parazitlenmemiş eritrositlerden daha büyüktürler. Enfekte eritrositlerin sitoplazması enfekte olmamış eritrositlerden daha koyudur. (Turkiye Parazitol Derg 2015; 39: 131-4)

Anahtar Sözcükler: Hemogregarin, Haemogregarina sundarbanensis n. sp., eritrosit, Hindistan Geliş Tarihi: 15.10.2014

Kabul Tarihi: 20.12.2014

Address for Correspondence / Yazışma Adresi: Probir K. Bandyopadhyay, Department of Zoology, Parasitology Laboratory, University of Kalyani, West Bengal, India. Phone: +919433214527 E-mail: prabir0432@hotmail.com DOI: $10.5152 /$ tpd.2015.3924

CTelif hakkı 2015 Türkiye Parazitoloji Derneği - Makale metnine www.tparazitolderg.org web sayfasından ulaşılabilir CCopyright 2015 Turkish Society for Parasitology - Available online at www.tparazitolderg.org 


\section{INTRODUCTION}

Intracellular haemogregarine parasites are often found in fresh water turtles, appearing as banana-shaped structures in the cytoplasm of the host erythrocytes. Haemogregarina stepanowi was first described from the European tortoise Emys orbicularis (Linn.) (1). Detailed account of the structure and life cycle of $H$. stepanowi in the same tortoise was established (2). After that, a number of studies have described different species from different parts of the world (3-8).

In India, chelonian haemogregarines were studied (9). The author described two species, $H$. laverani and $H$. mesnilli from Emydagranosa and Emys tectum, respectively. In 1983, Bhatia in his monumental works on Fauna of British India mentioned a number of haemogregarine species described by different researchers from India (10). Two new haemogregarines were also reported from West Bengal, India $(11,12)$. In 1932, de Mello established a new species of haemogregarine in India (13).

The present paper deals with a new haemogregarine that infects the erythrocytes of a common mud turtle, Lissemys punctata punctata (Bonnaterre), from Canning, Sundarbans region, West Bengal, India.

\section{METHODS}

The turtles were collected from fish markets near Canning, South 24-Parganas District, West Bengal. These turtles were reported to be collected from the ponds near Port Canning of the Sundarbans region, West Bengal, India in the months of March-April, 2012. Thin blood films were prepared using the blood drawn from the head and feet by hypodermic syringes. The turtles were kept alive in a small reservoir along with small fishes and water weeds, such as Hydrila, and were observed at regular intervals.
The blood films were then air-dried, fixed in absolute methanol, and stained with Giemsa. Photomicrographs were taken with the help of a Carl Zeiss high-resolution microscope using a Digital Olympus Camera. The measurement and volume of the different stages of the parasite was taken using the LAS software, version 4.1.0 (Leica, Watzlar, Germany). To visualize the periphery of the parasites, the outline drawings were done using the related software.

The Type slides bearing no. HG/PARA/12 has been deposited in the Parasitology Laboratory, Department of Zoology, University of Kalyani, Kalyani, West Bengal, India.

\section{RESULTS}

Haemogregarina sundarbanensis $\mathrm{n} . \mathrm{sp}$.

Type-host: Lissemys punctata punctata (Bonnaterre)

Type-locality: Champahati, Canning, South 24 Parganas, West Bengal

Site of infection: Erythrocytes

Prevalence: Out of the 15 turtles, five (33.3\%) were found to be infected.

Vector: Unknown

\section{Description}

\section{Young Gamonts}

They are elongated with one end narrower than the other which is blunt. They measure $7.896 \times 3.469 \mu \mathrm{m}$ with an average area of $20.794 \mu^{2}$. The cytoplasm is densely granular and stains light blue with Giemsa stain. The oval nucleus is central in position measuring $2.51 \times 1.80 \mu \mathrm{m}$. It was stained pink in color. The sexes cannot be separated in this stage (Figure $1 \mathrm{a}, \mathrm{b}$, Figure $2 \mathrm{a}$ ).

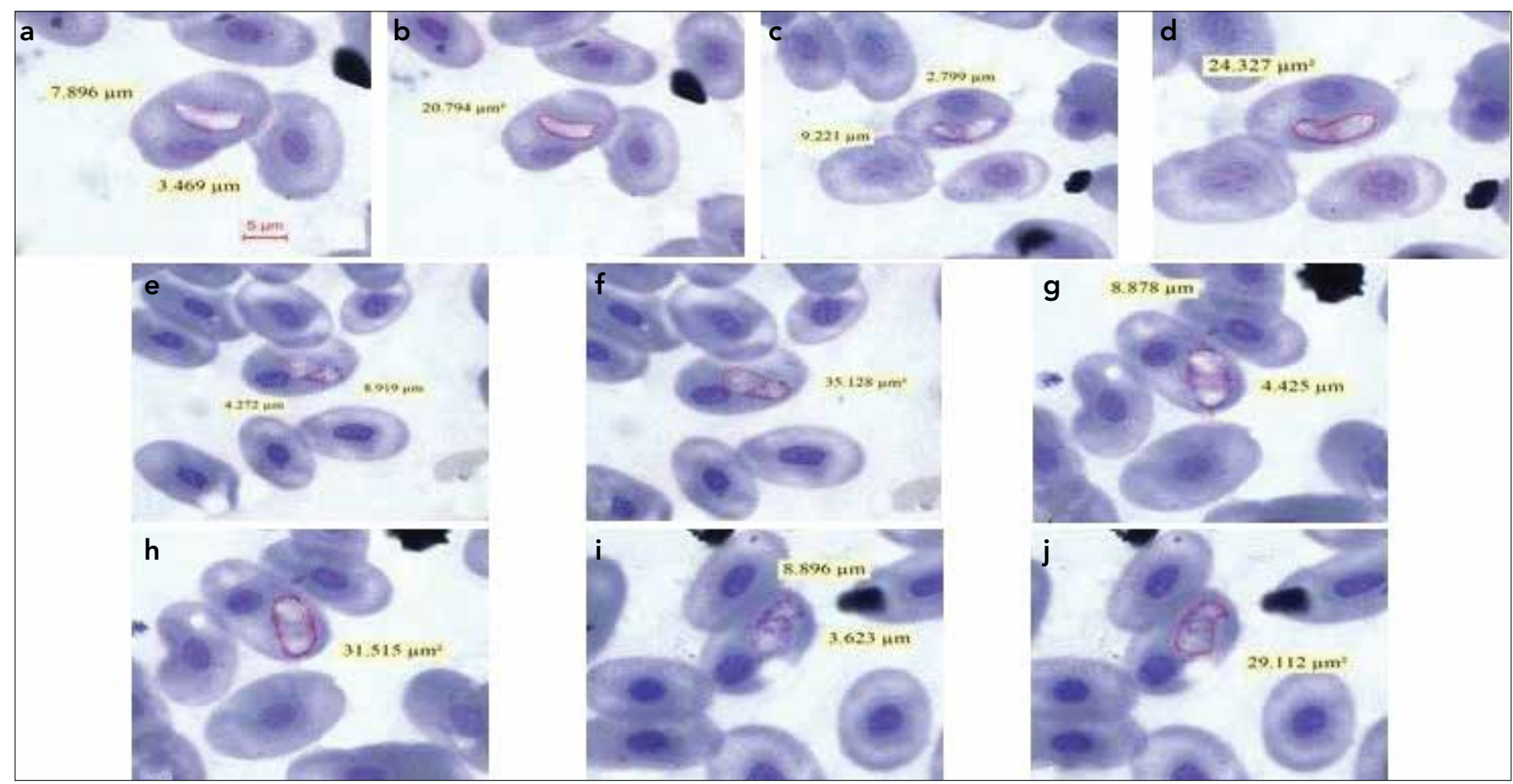

Figure 1. a-j. Multiple stages of intraerythrocytic haemogregarine gametocytes (a, b), young gamonts; (c, d), mature gamonts; (e, $f)$, macrogamonts; $(g, h)$, microgamonts; and erythrocytic schizogony $(i, j)$

The blood films were stained with Giemsa. The measurement and volume of the different stages of the parasite has been taken using the LAS software, version 4.1.0 (Leica, Watzlar, Germany). 
Table 1. Comparative morphometric measurements of different Haemogregarina sp. of turtle recorded from India (All measurements in micrometers)

\begin{tabular}{|l|l|l|l|l|}
\hline & $\begin{array}{l}\text { H. choudhuryi } \\
\text { Ray et al. (12), 1984 }\end{array}$ & $\begin{array}{l}\text { H. gangetica } \\
\text { Misra (11), 1976 }\end{array}$ & $\begin{array}{l}\text { H. xaveri } \\
\text { de Mello (13), 1932 }\end{array}$ & $\begin{array}{l}\text { H. sundarbanensis } \\
\text { n. sp. }\end{array}$ \\
\hline Macrogametocytes & $8.5 \times 3.5 \mu \mathrm{m}$ & $9.6 \times 4.8 \mu \mathrm{m}$ & $7.5-13.5 \mu \mathrm{m} \times 2.5-6.2 \mu \mathrm{m}$ & $8.919 \times 4.272 \mu \mathrm{m}$ \\
\hline Microgametocytes & $8.5 \times 2.0 \mu \mathrm{m}$ & $9.16 \times 3.20 \mu \mathrm{m}$ & $9-10 \mu \mathrm{m} \times 4.0 \mu \mathrm{m}$ & $8.876 \times 4.425 \mu \mathrm{m}$ \\
\hline Schizonts & $\begin{array}{l}\text { In erythrocytes and the } \\
\text { lung tissue }\end{array}$ & $\begin{array}{l}\text { In the lung tissue } \\
\text { Hosts }\end{array}$ & $\begin{array}{l}\text { In the lung, liver, } \\
\text { and spleen tissue }\end{array}$ & In erythrocytes \\
\hline
\end{tabular}

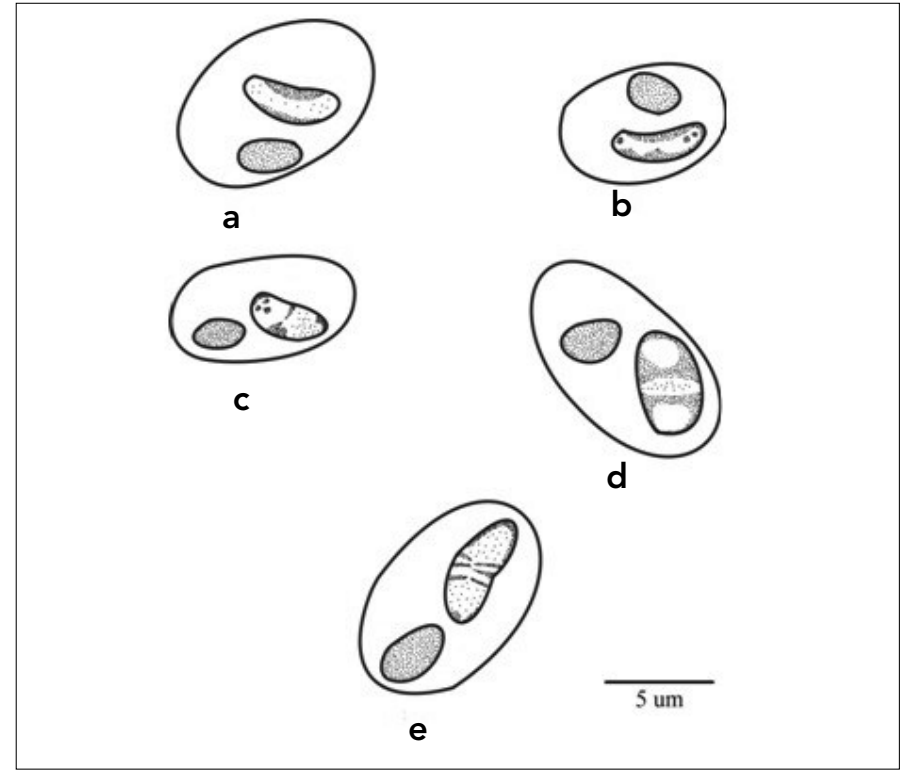

Figure 2. a-e. Drawings of multiple stages of intraerythrocytic haemogregarine gametocytes (a), young gamonts; (b), mature gamonts; (c), macrogamonts; (d), microgamonts; and (e), erythrocytic schizogony

\section{Mature Gamonts}

They are crescent shaped with both the ends rounded, measuring $9.221 \times 2.799 \mu \mathrm{m}$ with an average area of $24.327 \mu \mathrm{m}^{2}$. The cytoplasm is densely granular and stains blue with Giemsa stain. The sexes of the mature gamonts are quite apparent. The macrogamonts are elongated or "Banana-shaped" with both the ends equally rounded. The cytoplasm stains deep blue with Giemsa and many metachromatic granules are found uniformly distributed. The oval or rounded nucleus is central in position and stains deep red with Giemsa stain. They measure $8.919 \times 4.272$ $\mu \mathrm{m}$ with an average area of $35.128 \mu \mathrm{m}^{2}$. The microgamonts are smaller in size than the macrogamonts. They are also "kidney or bean shaped" with a few metachromatic granules and stains light blue with Giemsa. The nucleus is not at all compact but has a few dispersed chromatin granules. They measure $8.876 \times 4.425$ $\mu \mathrm{m}$ with an average area of $31.515 \mu \mathrm{m}^{2}$ (Figure $1 \mathrm{c}$-h, Figure 2 b-e).

\section{Infected Erythrocytes}

The infected erythrocytes demonstrate shape alteration, marginal and atrophic nucleus, and are larger than non-parasitized erythrocytes. The shape alterations consisted in lengthening of the red blood cells and presence of various abnormal shapes.
Sometimes, the nucleus of the infected erythrocytes is displaced at one end. The cytoplasm of the infected erythrocytes became darker than the uninfected erythrocytes.

\section{Erythrocytic Schizogony}

As the parasites enlarge, the cytoplasm becomes vacuolated and division of the nucleus is initiated. Many erythrocytic schizonts were observed in the red blood cells of the circulating blood. Binucleate and tetranucleate schizonts commonly occurr. Successive divisions result in the formation of eight merozoites. The mature schizonts measure $8.896 \times 3.623 \mu \mathrm{m}$ with an average area of $29.112 \mu^{2}$. The merozoites are elongated with both the ends tapering. They are measure $5.0 \times 1.0 \mu \mathrm{m}$ with a central oval nucleus (Figure $1 \mathrm{i}$, j, Figure 2 e).

\section{DISCUSSION}

After reviewing earlier research work, it can be reported that there are many species of chelonian haemogregarines reported both from India and abroad. Moreover, there is confusion regarding the taxonomic status of those species described.

The present species has some resemblances with Haemogregarina choudhuryi, H. balli, and H.stepanowi by having similar type of erythrocytic schizonts with 6-10 merozoites. However, it differs from them in the type of localization of schizonts. Reichnow (1910) observed 12-24 merozoites in the erythrocytic schizonts and bone marrow. Paterson et al. (6) (1976) recorded the presence of the schizont of $H$. balli in a variety of cells of the liver, lungs, and spleen. In contrast, $H$. sundarbanensis shows only erythrocytic schizonts. It has some similarities with $H$. pseudemydis by not having tissue schizonts, and it differs from the same species in having 35-140 merozoites in a schizont in the erythrocyte and leucocytes. In H. pseudemydis, the sporogonic development is also unknown (Table 1).

\section{CONCLUSION}

The parasite under report differs from all the haemogregarines described so far from turtles and tortoises in morphometric parameters and other characteristics in detail. Because of it novelty, it is designated as Haemogregarina sundarbanensis sp. n. as it is named after the locality from which it was obtained, i.e., the Sundarbans region of West Bengal, India.

Ethics Committee Approval: The approval of the ethics committee has not been obtained because the host animal has not been killed.

Informed Consent: N/A. 
Peer-review: Externally peer-reviewed.

Author Contributions: Concept - P.K.B.; Design - P.K.B.; Supervision P.K.B.; Data Collection and/or Processing - S.H.M.; Analysis and/or Interpretation - P.K.B., G.G.; Literature Review - S.H.M.; Writer -S.H.M.

Acknowledgements: One of the authors (Sabir Hossen Molla) is thankful to the Head of the Department of Zoology, University of Kalyani, Nadia, West Bengal, for providing necessary laboratory facilities.

Conflict of Interest: No conflict of interest was declared by the authors.

Financial Disclosure: The authors declared that this study has received no financial support.

Etik Komite Onayı: Çalışma hayvanlara zarar verilmeden yürütüldüğünden etik komite onayı alınmamıştır.

Hasta Onamı: N/A.

Hakem Değerlendirmesi: Dış Bağımsız.

Yazar Katkıları: Fikir - P.K.B.; Tasarım - P.K.B.; Denetleme - P.K.B.; Veri Toplanması ve/veya işlemesi - S.H.M.; Analiz ve/veya Yorum - P.K.B., G.G.; Literatür taraması - S.H.M.; Yazıyı Yazan - S.H.M.

Teşekkür: Yazarlardan Sabir Hossen Molla'ya (Kalyani Üniversitesi Zooloji Anabilim Dalı, Nadia, Batı Bengal) çalışmaya sağladığı laboratuar olanaklarından dolayı teşekkür ederiz.

Çıkar Çatışması: Yazarlar herhangi bir çıkar çatışması bildirmemişlerdir.

Finansal Destek: Yazarlar bu çalışma için finansal destek almadıklarını beyan etmişlerdir.

\section{REFERENCES}

1. Danilewsky B. Die Hamatozoen der kaltbluter. Arch Mikrosk Anat 1885; 24: 588-98. [CrossRef]
2. Reichnow E. Haemogregarina stepanowi, Die Entwicklungsgeschichteeiner Haemogregarine. Arch Protistenk 1910; 20: 251-350.

3. Wang CC, Hopkins SH. Haemogregarina and haemoproteus (Protozoa: Sporozoa) in blood of Texas freshwater turtles. JParasitol 1965; 51: 682-3. [CrossRef]

4. Desser SS. A description of intraerythrocytic schizonts and gametocytes of a haemogregarine of the snapping turtle, Chelydra serpentina. Can J Zool 1973; 51: 431-2. [CrossRef]

5. Acholonu AD. Haemogregarina pseudemydis sp. n. (Apicomplexa: Haemogregarinidae) and Pirhemocyton chelonarum sp. n. in turtles from Louisiana. J Protozool 1974; 21: 659-64. [CrossRef]

6. Paterson WB, Desser SS. Observation on Haemogregarina balli sp. n. from the common snapping turtle, Chelydra serpentine. J Protozool 1976; 23: 294-301. [CrossRef]

7. Siddal ME, Desser SS. Prevalence and intensity of Haemogregarina balli (Apicomplexa, Adeleina: Haemogregarinidae) in three turtle species from Ontario, with observations on intraerythrocytic development. Can J Zool 1992; 70: 123-8. [CrossRef]

8. Davis AK, Sterrett SC. Prevalence of Haemogregarine parasites in three freshwater turtle species in a population in Northeast Georgia, USA. Int J Zool Res 2011; 7: 156-63. [CrossRef]

9. Simond PL. Contribution al etude des hematozoires endoglobulaires des reptiles. Annis Inst Pasteur Paris 1901; 15: 319.

10. Bhatia BL. Protozoa: Sporozoa. The fauna of British India including Ceylon and Burma. London: Taylor \& Francis; 1938.

11. Misra KK. Haemogregarina gangetica, a new name for Haemogregarina simondi of a river turtle Trionyx gangeticus Cuvier. Acta Protozool 1976; 15: 21-2.

12. Ray R, Bhattacharjee A. Haemogregarina choudhury choudhuryi sp. n. (Apicomplexa: Haemogregarinidae) in Common Pond Water Turtle, Lissemys punctata punctata (Bonnaterre) from West Bengal. Acta Protozool 1984; 23: 67-74.

13. de Mello. Haemogregarina xaveri, a new species of haemogregarine from Nova Goa. Arch. Esc., Med. Cirrug., Nova Goa, Ser. A. 1932; 8: 1411-2. 